\title{
SISTEM PENDUKUNG KEPUTUSAN PENENTUAN PRIORITAS PEMILIHAN TRAVEL UMROH PADA PT AMANAH UMROH HANDAL DENGAN METODE SIMPLE ADDICTIVE WEIGHTING (SAW) BERBASIS WEB-BASED
}

\author{
Sugeng Widjayanto ${ }^{1}$, Joko Sutrisno ${ }^{2)}$ \\ ${ }^{1}$ Sistem Informasi, Fakultas Teknologi Informasi, Universitas Budi Luhur \\ ${ }^{1,2} \mathrm{Jl}$. Raya Ciledug, Petukangan Utara, Kebayoran Lama, Jakarta Selatan 12260 \\ E-mail : sugengwidjayanto11@gmail.com ${ }^{1)}$,joko.sutrisno@budiluhur.ac.id ${ }^{2)}$
}

\begin{abstract}
Abstrak
PT Amanah Umroh Handal adalah marketplace para travel umroh untuk pencarian travel umroh terpadu. Demi kenyamanan dan kemudahan, PT Amanah Umroh Handal menyediakan sejumlah besar paket perjalanan oleh berbagai perusahaan travel umroh di seluruh indonesia. Pemilihan travel umroh harus dengan cara yang tepat untuk mendapatkan pelayanan yang bagus bagi jamaah yang ingin berangkat umroh. Antusias masyarakat untuk melakukan ibadah umroh semakin tinggi dan masyarakat ingin melakukan ibadah umroh dengan rasa nyaman dan aman. Maka pihak PT. Amanah Umroh Handal memfasilitasi dan bermitra dengan para travel umroh agar transaksi jamaah aman dan nyaman terlepas dari kebutuhan pada sistem pendukung keputusan dalam menentukan pemilihan travel umroh serta sistem yang memudahkan jamaah untuk memilih travel umroh yang aman, sehingga keberlangsungan pemberangkatan ibadah umroh tidak menjadi terkendala dan selalu aman. Penulis mengangkat permasalahan ini dengan melakukan penelitian sistem yang berjalan di PT. Amanah Umroh Handal dan melakukan perancangan sistem pendukung keputusan prioritas pemilihan travel umroh dengan metode SAW (Simple Additive Weighting) dalam bentuk aplikasi berbasis Web-Based.
\end{abstract}

Kata kunci: SAW (Simple Additive Weighting), Sistem SPK, SPK Travel Umroh, Aplikasi SPK Travel Umroh.

\section{PENDAHULUAN}

PT Amanah Umroh Handal adalah marketplace para travel umroh untuk pencarian travel umroh terpadu. Demi kenyamanan dan kemudahan, PT Amanah Umroh Handal menyediakan sejumlah besar paket perjalanan oleh berbagai perusahaan travel umroh di seluruh indonesia Untuk itu dibutuhkan suatu sistem penunjang keputusan, dimana sistem yang dimaksud adalah suatu sistem yang berbasis web-based yang ditunjukan untuk membantu berbagai persoalan yang kurang terstruktur.

Masalah yang terjadi di obyek penelitian sebagai berikut :

a) Pemilihan travel umroh yang masih belum di dukung oleh sistem penunjang keputusan sehingga menyulitkan pihak manajemen PT. Amanah Umroh Handal

b) Masalah-Masalah yang saat ini masih belum terbantu sistem penunjang keputusan di PT. Amanah Umroh Handal untuk pengambilan keputusan. Misalkan penilaian kriteria, penilaian alternatif dan hasil analisa perhitungan keputusan.

Adapun tujuan yang akan diperoleh dari penelitian ini adalah:

1) Perancangan sistem membantu proses seleksi penerimaan travel umroh, pengelolaan data alternatif travel umroh, kriteria travel umroh dan nilai kriteria travel umroh.

2) Adanya sistem penunjang keputusan diharapkan pihak PT. Amanah Umroh Handal menjadi lebih tersistematis dan efesien dalam menentukan keputusan.

\section{STUDI PUSTAKA}

\subsection{Konsep Dasar Sistem Informasi}

Pengertian sistem menurut Romney dan Steinbart (2015:3) [1] Sistem adalah rangkaian dari dua atau lebih komponen-komponen yang saling berhubungan, yang berinteraksi untuk mencapai suatu tujuan.Sebagian besar sistem terdiridari subsistem yang lebih kecil yang mendukung sistem yang lebih besar

\subsection{Metode Simple Additive Weighting}

a. Tentukan kriteria-kriteria yang akan dijadikan acuan dalam pengambilan keputusan, yaitu Ci (Criteria i) dan SCi (Sub Criteria i).

b. Tentukan kriteria mana sebagai atribut keuntungan (benefit) atau biaya (cost), lalu tentukan nilai bobot masing-masing kriteria

c. Tentukan rating kecocokan setiap alternatif pada setiap kriteria 
d. Membuat matriks keputusan berdasarkan kriteria (Ci), kemudian melakukan normalisasi matriks berdasarkan persamaan yang disesuaikan dengan jenis atribut (keuntungan/biaya) sehingga diperoleh matriks ternormalisasi $\mathrm{R}$

\subsection{Teori- Teori Pendukung Lainnya}

a. Flowmap

Adapun pedoman-pedoman dalam pembuatan flowmap adalah sebagai berikut :

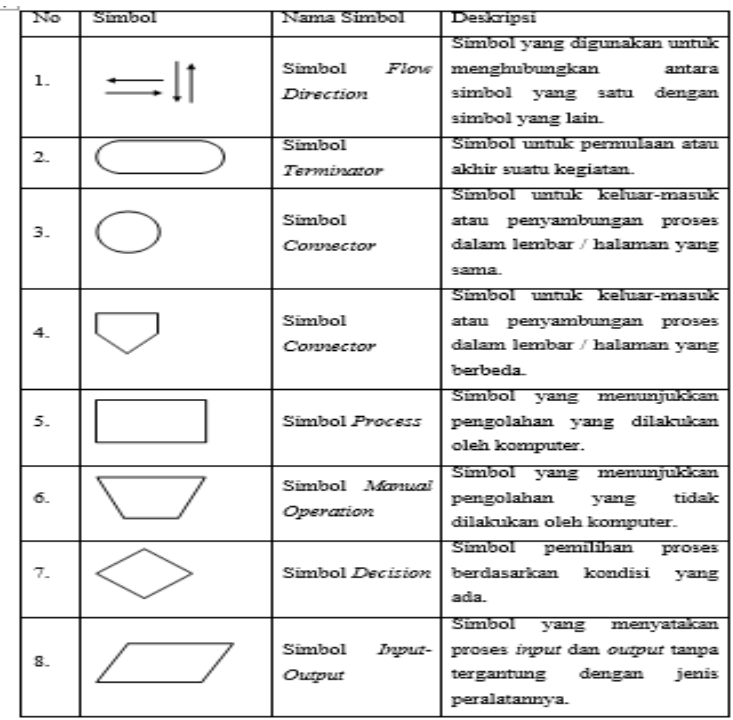

Gambar 1. Daftar Simbol Flowmap

b. Activity Diagram

Diagram aktivitas atau activity diagram menggambarkan berbagai kegiatan userworkflow. Yang perlu diperhatikan di sini adalah bahwa diagram aktivitas menggambarkan aktivitas sistem, bukan apa yang dilakukan aktor, jadi aktivitas yang dapat dilakukan oleh system

c. Pustaka

Banyak penelitian yang telah dilakukan sebelumnya mengenai Implementasi Sistem Penunjang Keputusan Simple Additive Weight (SAW), diantaranya adalah :

Judul : Sistem Pendukung Keputusan Pemilihan Supplier Terbaik Telur Bermerk Menggunakan Metode SAW Studi Kasus : PT. GIANT PONDOK KOPI

Penulis : Hariyanto \& Siti Khotimah

Bentuk : Jurnal / ISSN : 2530-1945

Terbitan: Jurusan Manajemen Informatika, STMIK Nusa Mandiri.

Tahun : 2018

Kesimpulan :

Kesimpulan pembahasan penelitian adalah sebagai berikut :
1. Sistem pemilihan supplier terbaik telur bermerk dengan menerapkan metode perhitungan Simple Additive Weighting (SAW) mempercepat proses seleksi pemilihan supplier terbaik.

2. Dapat menghasilkan rekomondasirekomendasi supplier secara tepat dan cepat pada Giant Supermarket Pondok Kopi khususnya. [2]

\section{METODE PENELITIAN}

Langkah-langkah penyelesaian Simple Additive Weighting (SAW): Tentukan kriteria mana sebagai atribut keuntungan (benefit) atau biaya (cost), lalu tentukan nilai bobot masing-masing kriteria.

Berikut adalah rumus mencari rating kinerja ternormalisasi sebagaimana ditampilkan pada gambar 2.

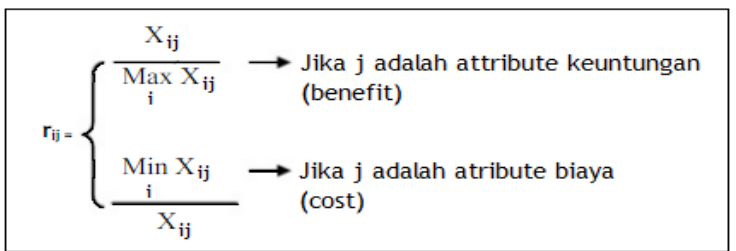

Gambar 2. Rumus Mencari Nilai Rating Kinerja Ternormalisasi

\subsection{Metode Pengumpulan Data}

Guna memperoleh data-data sebagai bahan penyusunan untuk penelitian ini penulis mengumpulkan data-data dari tempat riset dengan melakukan beberapa metode pengumpulan data sebagai berikut:

a. Wawancara

Pengumpulan data-data asli dilakukan dengan cara wawancara atau bertanya langsung melalui tatap muka dengan pihak PT. Amanah Umroh Handal

b. Kusioner

Kusioner ini merupakan proses pengumpulan data yang digunakan untuk mengetahui tanggapan terhadap pertanyaan yang diajukan. Hasil kusioner yang diperoleh dari tanggapan, didapatkan satu hasil yang akan digunakan untuk menentukan prioritas pemilihan biro umroh pada pada PT. Amanah Umroh Handal

c. Studi Kepustakaan

Hasil penelitian yang sudah ada dijadikan suatu perbandingan dan masukan untuk penyelesaian permasalahan yang sama atau hampir sama agar pengembangan sistem menjadi lebih terarah dan variatif. 


\subsection{Instrumentasi}

Wawancara dilakukan oleh Manajemen PT. Amanah Umroh Handal pada saat pengambilan keputusan di PT. Amanah Umroh Handal untuk memperoleh informasi tentang bagaimana menentukan prioritas pemilihan biro umroh yang dilakukan oleh PT. Amanah Umroh Handal.

\subsection{Komponen Sistem Penunjang}

Keputusan

Menurut Turban (Turban et al, 2013) [3] berikut komponen sistem penunjang keputusan yang dapat dibangun berdasarkan gambar berikut :

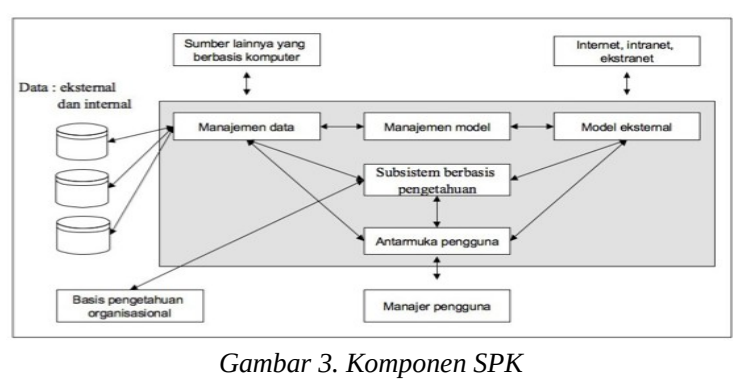

Penjelasan Gambar 3:

a. Subsistem Manajemen Data (Data Management Subsystem)

Data Internal dalam aplikasi ini adalah data yang diperoleh dari pemilik PT. Amanah Umroh Handal. Data ekstenal dalam aplikasi ini adalah data b. Subsistem Manajemen Model (Model Manahement Subsystem)

Perangkat ini sering disebut Model Base Management System (MBMS) dan dalam pembuatan sistem penunjang keputusan ini menggunakan bahasa pemograman PHP 5.6 dengan tools Sublime dan database tools MySQL

c. Subsistem antaramuka pengguna (User Interface Subsytem)

Pengguna dapat berkomunikasi dan memerintahkan sistem penunjang keputusan melalui subsystem ini. input data yang ada adalah donasi, data yatim dhuafa dan kriteria yang menentukan proses prioritas pemilihan biro umroh di PT. Amanah Umroh Handal

d. Subsistem Manajemen Pengetahuan (Knowledge Management Subsystem)

Subsystem ini dapat mendukung semua subsystem lain atau bertindak sebagai komponen independen. Memberikan inteligensi untuk memperbesar pengetahuan kepada manajemen PT. Amanah Umroh Handal mampu menginterkoneksikan dengan repository pengetahuan yang biasa disebut dengan Organizational Knowledge Base.

\subsection{Proses Bisnis dalam Pengambilan Keputusan}

Penentuan pemilihan travel umroh pada PT. Amanah dilakukan tidak menentu. Proses penentuan pemilihan travel dilakukan oleh Pihak Komersial Departement dan bagian penilaian dengan cara bermusyawarah.

Proses dimulai dari kepala komersial departement menyiapkan data travel untuk bahan pertimbangan saat musyawarah kemudian menyerahkannya kepada bagian penilaian dan akan mengecek apakah data lengkap. Jika data tidak lengkap bagian penilaian akan mengembalikan kepada divisi komersial untuk melengkapi jika lengkap data akan diserahkan kepada kepala bagian komersil kemudian kepala komersil akan menginformasikan kepada bagian penilaian. Bagian penilaian akan memberikan informasi dan masukan mengenai travel umroh yang layak menjadi mitra travel umroh. Jika penilaian antara bagian penilaian dan Kepala bagian Komersil berbeda Kepala bagian komesil akan meminta penilaian masukan ulang jika sama Kepala Bagian Komersil mengecek data travel untuk bahan pertimbangan saat mengambil keputusan. Pengambilan keputusan dilakukan saat dirasa penilaian kepala bagian komersil dan bagian penilaian sudah tepat barulah dapat diambil keputusan pemilihan travel umroh. Proses berjalan ini dijelaskan pada activity diagram gambar 6

Setelah travel umroh sudah ditentukan Kepala Bagian Komersil akan memberikan surat kerja sama sebagai bentuk apresiasi kepada travel umroh yang layak menjadi mitra travel umroh. Proses berjalan ini dijelaskan pada activity diagram gambar 7

\section{HASIL DAN PEMBAHASAN}

\subsection{Manfaat}

Manfaat yang akan diperoleh dari penelitian ini adalah :

1. Dengan adanya sistem penunjang keputusan berbasis web maka dapat membantu pihak PT Amanah Umroh Handal menghasilkan suatu keputusan dalam hal menentukan prioritas pemilihan travel umroh.

2. Mengetahui metode SAW (Simple Addictive Weighting) dapat digunakan dalam sistem pengambilan keputusan

3. Mempermudah merekapitulasi data biro dalam mengambil nilai perhitungan pada travel umroh.

\subsection{Tool Menganalisis Permasalahan}

Berikut adalah diagram fishbone sebagaimana ditampilkan pada gambar 4 . 


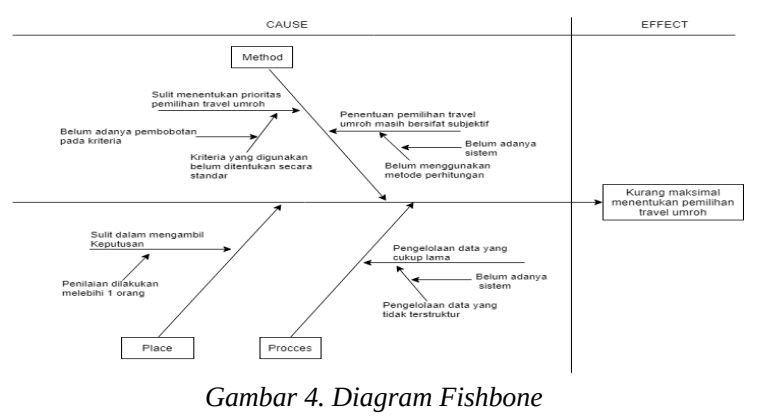

Permasalahan pada proses, sulitnya Direktur dalam mengambil keputusan dikarenakan penilaian travel umroh dilakukan lebih dari 1 orang sulit dalam mempertimbangkan dan juga tidak adanya keputusan perangkingan hasil akhir sehingga penilaian kurang maksimal.

\subsection{Struktur Organisasi}

Adapun struktur organisasi yang ada pada PT. Amanah Umroh Handal adalah sebagai berikut :

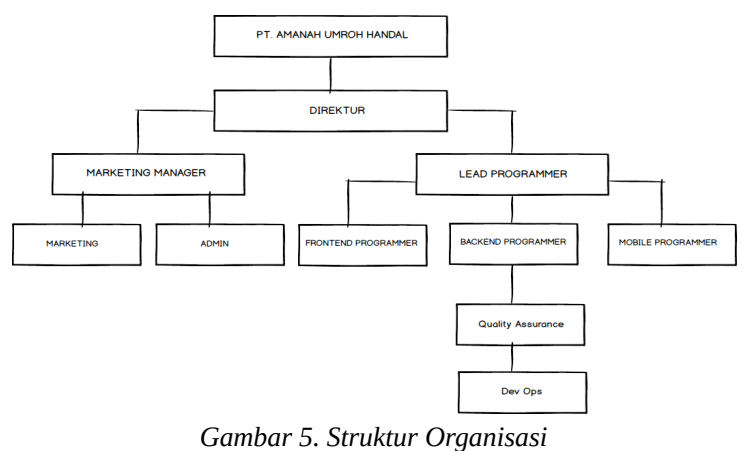

\subsection{Activity Diagram penentuan pemilihan} travel umroh

Berikut adalah gambar Activity Diagram penentuan pemelihan travel umroh sebagaimana ditampilkan pada gambar 6 .

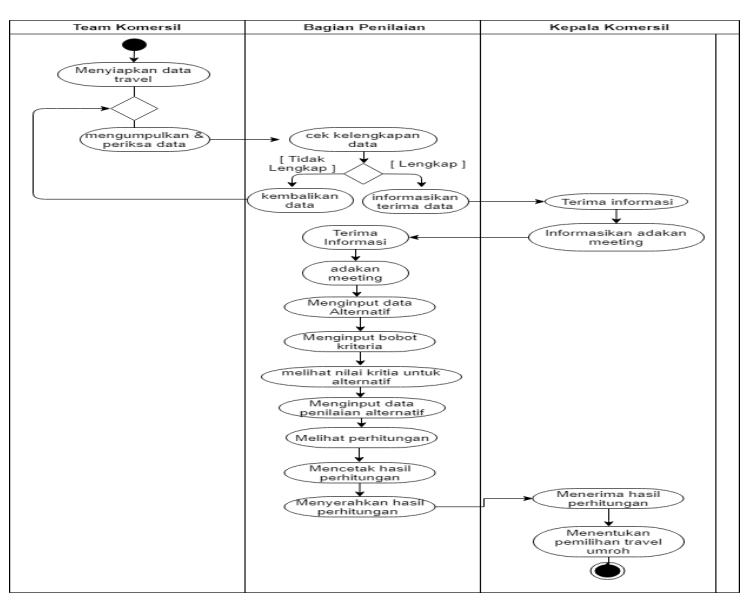

Gambar 6. Activity Diagram Penentuan Pemilihan Travel Umroh

\subsection{Activity Diagram kerja sama travel umroh}

Berikut adalah Activity Diagram kerja sama travel umroh sebagaimana ditampilkan pada gambar 7.

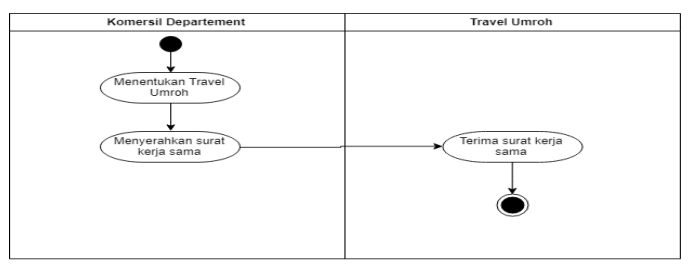

Gambar 7. Activity Diagram Kerja sama Travel Umroh

\subsection{Identifikasi Kriteria}

Kriteria yang telah ditentukan penulis untuk menentukan prioritas penerima santunan ada empat, yaitu: Legalitas Travel Umroh, Jumlah Pemberangkatan, Kualitas Pelayanan dan Sarana dan Prasarana.

a. Legalitas Travel Umroh

Setiap Travel Umroh harus mempunyai legalitas untuk meningkatkan SOP atau Prosedur layak menjadi Travel Umroh.

b. Jumlah Pemberangkatan

Jumlah Pemberangkatan jamaah salah satu unsur pemilihan untuk meningkatan kepercayaan jamaah

c. Kualitas Pelayanan

Kualitas Pelayanan Sangat Penting untuk pendekatan transaksi berkala pada calon jamaah

d. Sarana dan Prasarana

Sarana dan Prasanan sangat penting untuk meningkat kenyamanan calon jamaah.

\subsection{Identifikasi Alternatif}

Alternatif yang ditentukan oleh rekaman PT amanah umroh handal sebanyak 10 data :

a Identifikasi Alternatif

Berikut adalah daftar data alternatif sebagaimana ditampilkan pada gambar 8 .

\begin{tabular}{|l|l|}
\hline Kode & Nama Aternatif \\
\hline A01 & Asri Gemilang Trip \\
\hline A02 & Menara Wisata \\
\hline A03 & A1iaGo \\
\hline A04 & Musfiratur \\
\hline A05 & Mubina Tours \\
\hline A06 & Fio Holiday \\
\hline A07 & A1 Balad A1 Ameen \\
\hline A08 & $\begin{array}{l}\text { Patih Indo Tours \& Haji } \\
\text { Umroh }\end{array}$ \\
\hline A09 & Annisa Trave1 \\
\hline A10 & Tiga Cahaya Utama \\
\hline
\end{tabular}

Gambar 8. Data Alternatif 
Langkah-langkah penyelesaian Simple Additive Weighting (SAW) :

1) Tentukam kriteria-kriteria yang akan dijadikan acuan dalam pengambilan keputusan, yaitu Ci (Criteria i) dan SCi (Sub Criteria i).

2) Tentukan kriteria mana sebagai atribut keuntungan (benefit) atau biaya (cost), lalu tentukan nilai bobot masing-masing kriteria.

3) Tentukan rating kecocokan setiap alternatif pada setiap kriteria.

4) Membuat matriks keputusan berdasarkan kriteria (Ci), kemudian melakukan normalisasi matriks berdasarkan persamaan yang disesuaikan dengan jenis atribut (keuntungan/biaya) sehingga diperoleh matriks ternormalisasi $\mathrm{R}$.

5) Hasil akhir diperoleh dari proses perangkingan yaitu penjumlahan dari perkalian matriks ternormalisasi $\mathrm{R}$ dengan vektor bobot sehingga diperoleh nilai terbesar yang dipilih sebagai alternatif terbaik (Ai) sebagai solusi.

\subsection{Pengolahan Data}

Berikut adalah gambar pengolahan data sebagaimana ditampilkan pada gambar 9 .

\begin{tabular}{|l|l|l|l|l|l|}
\hline Kode & $\begin{array}{l}\text { Nama } \\
\text { Aternatif }\end{array}$ & Legalitas & $\begin{array}{l}\text { Jumlah } \\
\text { Pemberangkatan }\end{array}$ & $\begin{array}{l}\text { Kualitas } \\
\text { Pelayanan }\end{array}$ & $\begin{array}{l}\text { Sarana dan } \\
\text { Prasaranan }\end{array}$ \\
\hline A01 & $\begin{array}{l}\text { Asri } \\
\text { Gemilang } \\
\text { Trip }\end{array}$ & 2 & 3 & 900 & 3 \\
\hline A02 & $\begin{array}{l}\text { Menara } \\
\text { Wisata }\end{array}$ & 1 & 2 & 900 & 4 \\
\hline A03 & AliaGo & 4 & 2 & 2500 & 2 \\
\hline A04 & Musfiratur & 1 & 1 & 4000 & 4 \\
\hline A05 & $\begin{array}{l}\text { Mubina } \\
\text { Tours }\end{array}$ & 1 & 5 & 3000 & 4 \\
\hline A06 & Fio Holiday & 3 & 1 & 900 & 1 \\
\hline A07 & $\begin{array}{l}\text { Meida } \\
\text { Wisata }\end{array}$ & 2 & 2 & 3000 & 3 \\
\hline A08 & $\begin{array}{l}\text { A1Balad A1 } \\
\text { Ameen }\end{array}$ & 1 & 4 & 700 & 4 \\
\hline A09 & $\begin{array}{l}\text { Path Indo } \\
\text { Tours \& } \\
\text { Haji Umroh }\end{array}$ & 2 & 3 & 4000 & 3 \\
\hline A10 & $\begin{array}{l}\text { Annisa } \\
\text { Travel }\end{array}$ & 1 & 2 & 700 & 4 \\
\hline
\end{tabular}

Gambar 9. Pengolahan Data

Tabel 1. Subkriteria Jumlah Pemberangkatan

\begin{tabular}{ll}
\hline Keterangan (Jamaah / Tahun) & Bobot \\
\hline $501-1000$ & 5 \\
$201-500$ & 4 \\
$101-200$ & 3 \\
$51-100$ & 2 \\
$1-50$ & 1 \\
\hline
\end{tabular}

\subsection{ERD (Entity Relation Diagram)}

Entity Relationship Diagram (ERD) ini berisi komponen-komponen himpunan entitas dan himpunan relasi. Masing-masing dilengkapi dengan atribut-atribut yang mewakili seluruh data yang ada. Seperti terlihat pada Gambar 10 berikut ini

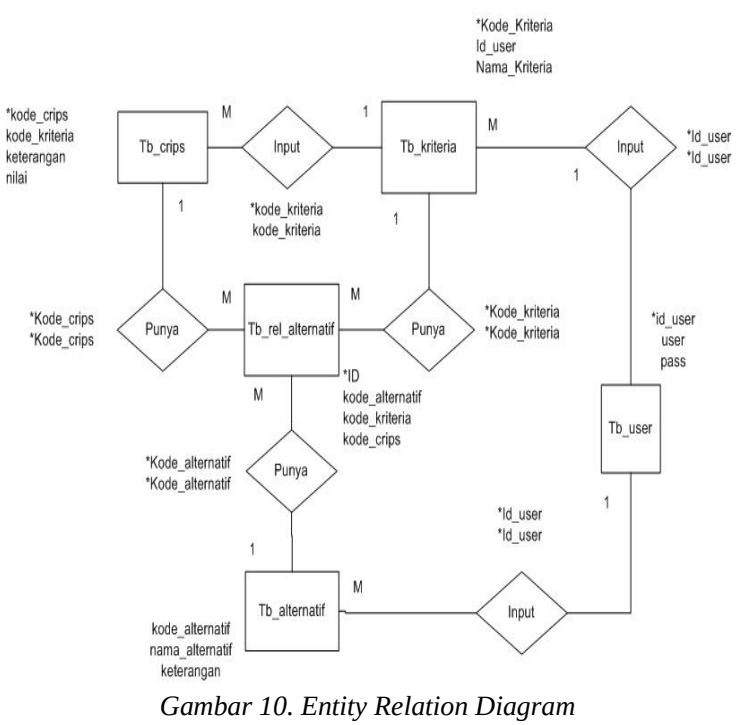

\subsection{Use Case Diagram}

Use Case Diagram menggambarkan sebuah interaksi antara actor dengan sistem. Use Case Diagram yang dibuat oleh peneliti disesuaikan dengan identifikasi kebutuhan yang dibuat pada tahapan sebelumnya.

a Use Case Diagram Login

Berikut adalah gambar use case diagram login sebagaimana ditampilkan pada gambar 11 .

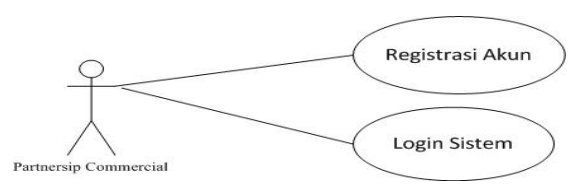

Gambar 11. Use Case Login

b Use Case Diagram Input

Berikut adalah gambar use case diagram input sebagaimana ditampilkan pada gambar 12 .

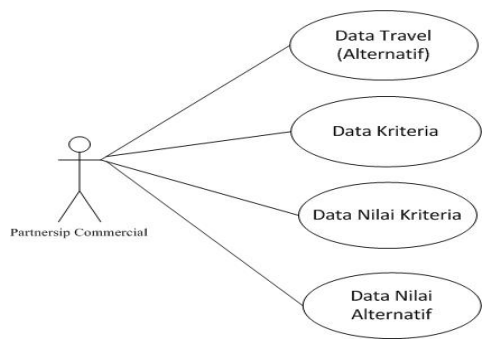

Gambar 12. Use Case Diagram Input

c Use Case Proses

Berikut adalah gambar use case diagram proses sebagaimana ditampilkan pada gambar 13 . 


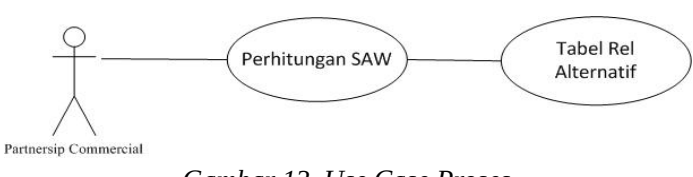

Gambar 13. Use Case Proses

d Use Case Laporan

Berikut adalah gambar use case diagram laporan sebagaimana ditampilkan pada gambar 14 .

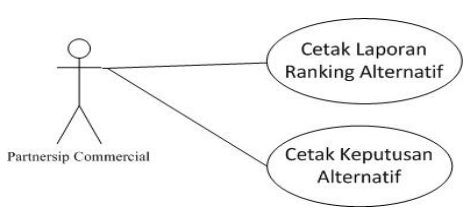

Gambar 14. Use Case Laporan

\subsection{Tabel Rel Alternatif}

Nama Table : tb_rel_alternatif

Isi : Data Relasi Alternatif

Media : Harddisk

Primary Key : ID

Struktur

Berikut adalah gambar struktur table tb_rel alternatif sebagaimana ditampilkan pada gambar 15.

\begin{tabular}{|l|l|l|l|}
\hline Nama Field & Type & $\begin{array}{l}\text { Ukura } \\
\text { n }\end{array}$ & Keterangan \\
\hline ID & Varchar & 16 & ID Rel Alternatif \\
\hline kode_alternatif & Varchar & 16 & Kode Alternatif \\
\hline kode_kriteria & Varchart & 16 & Kode Kriteria \\
\hline kode_crips & Varchar & 16 & Kode Sub Kriteria \\
\hline
\end{tabular}

Gambar 15. Struktur Table tb_rel_alternatif

\subsection{Rancangan Layar Login}

Halaman Login ini berfungsi untuk masuk ke halaman utama, sebelum masuk ke halaman utama user wajib mengisi username dan password. Seperti terlihat di Gambar 16.

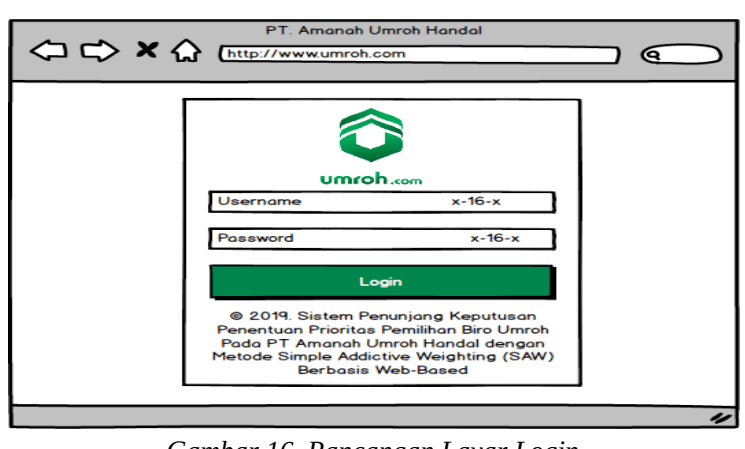

Gambar 16. Rancangan Layar Login

\subsection{Rancangan Layar Home}

Halaman Home ini adalah halaman utama aplikasi. Seperti terlihat di Gambar 17.

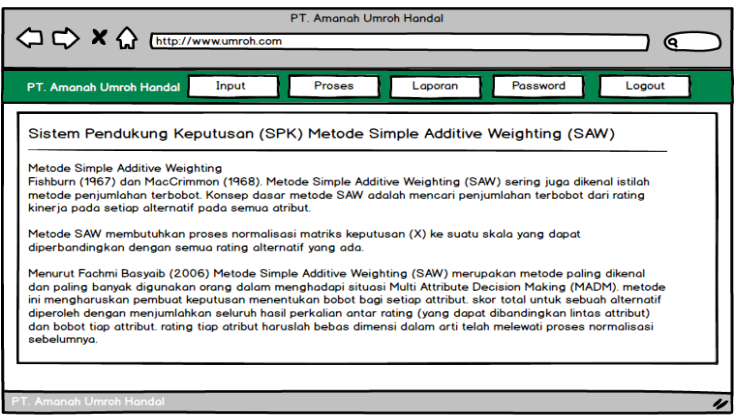

Gambar 17. Rancangan Layar Home

\subsection{Rancangan Layar Nilai Kriteria}

Berikut adalah gambar rancangan layar nilai kriteria sebagaimana ditampilkan pada gambar 18.

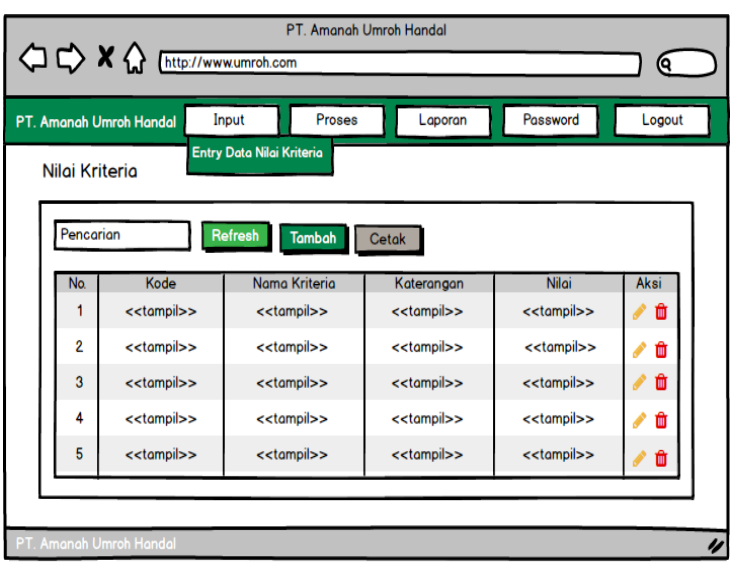

Gambar 18. Rancangan Layar Nilai Kriteria

\subsection{Rancangan Layar Alternatif}

Berikut adalah gambar rancangan layar pada alternatif sebagaimana ditampilkan pada gambar 19.

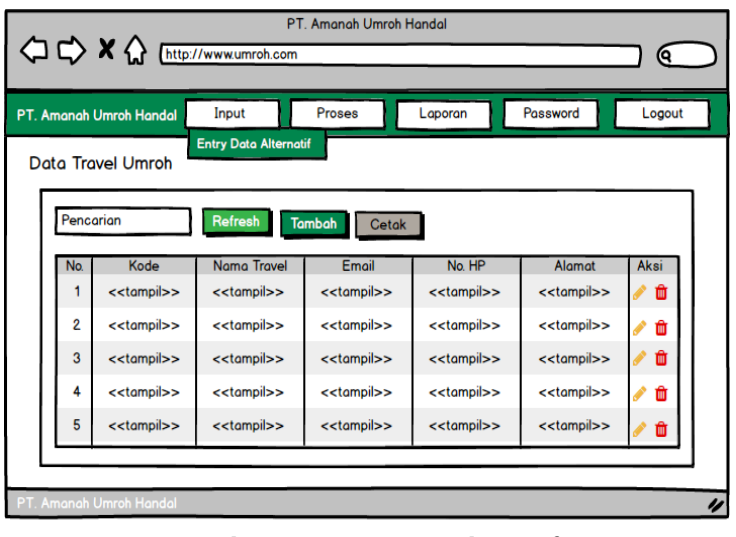

Gambar 19. Rancangan Alternatif 


\subsection{Rancangan Layar Perhitungan}

Berikut adalah gambar rancangan layar pada perhitungan sebagaimana ditampilkan pada gambar 20.

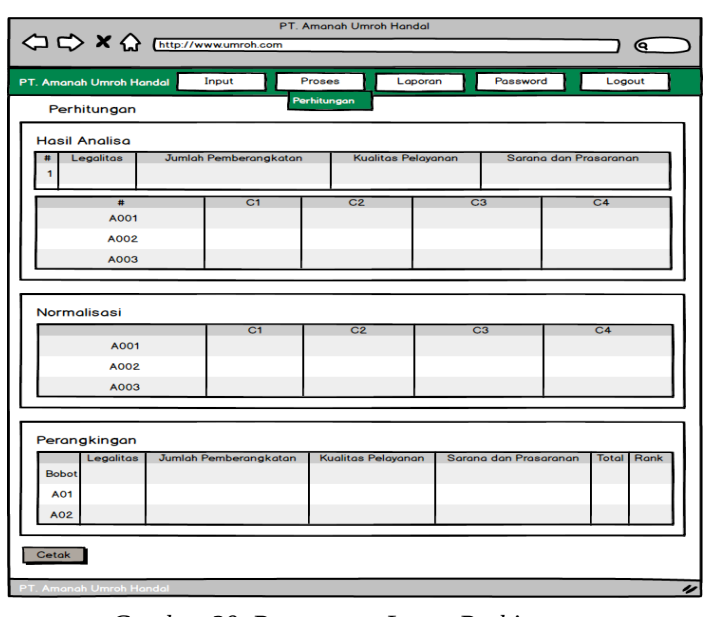

Gambar 20. Rancangan Layar Perhitungan

\subsection{Rancangan Layar Tambah Kriteria}

Berikut adalah gambar rancangan layar pada tambah kriteria sebagaimana ditampilkan pada gambar 21.

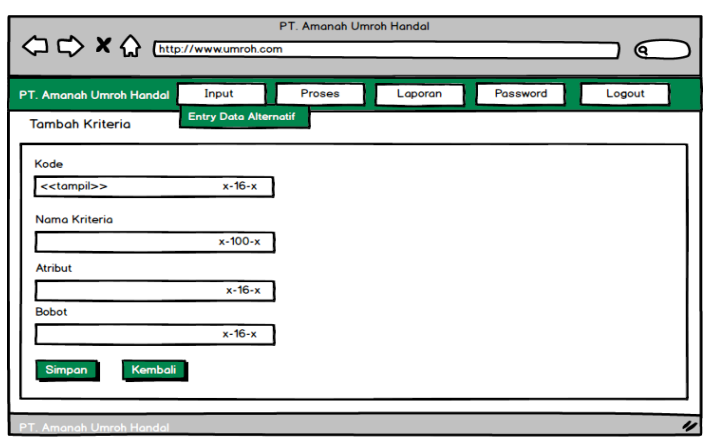

Gambar 21. Rancangan Layar Tambah Kriteria

\subsection{Rancangan Layar Ubah Kriteria}

Berikut adalah gambar rancangan layar pada ubah kriteria sebagaimana ditampilkan pada gambar 22.

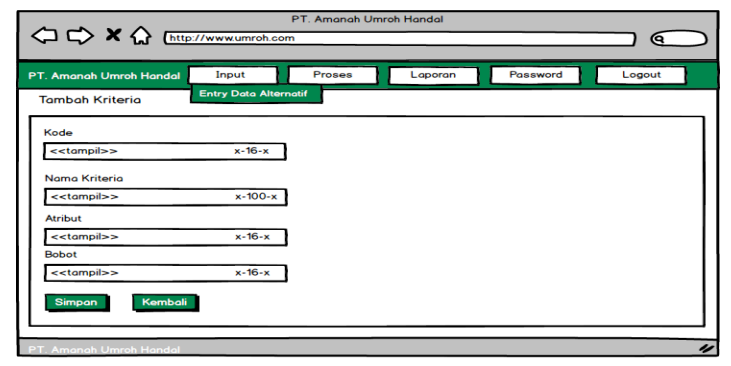

Gambar 22. Rancangan Layar Ubah Kriteria

\section{KESIMPULAN}

Berdasarkan hasil penelitian pada tiap-tiap bab diatas maka peneliti dapat menyimpulkan tentang beberapa hal, sebagai berikut:

1. Perancangan sistem membantu proses seleksi penerimaan travel umroh, pengelolaan data alternatif travel umroh, kriteria travel umroh dan nilai kriteria travel umroh.

2. Adanya sistem penunjang keputusan diharapkan pihak PT. Amanah Umroh Handal menjadi lebih tersistematis dan efesien dalam menentukan keputusan.

Sistem yang di ajukan ;

1. Sistem yang diajukan memudahkan pihak PT Amanah Umroh Handal dalam melihat urutan pemilihan travel umroh.

2. Pengembangan yang dilakukan dalam penelitian ini adalah dengan memasukkan atribut prioritas yang digunakan untuk perhitungan terhadap nilai

\section{DAFTAR PUSTAKA}

[1] Dennis, System Anlysis \& Design Fifth Edition, United States of America: John Wiley \& Sons, Inc, 2012.

[2] Kadir, "Pengertian Sistem Informasi," Tangerang, Nur Azizah, 2014, p. 9.

[3] Al-Bahra, Pengertian informasi, Tangerang: Alfharabi Saktiamanta, 2013.

[4] S. K. Hariyanto, Sistem Pendukung Keputusan Pemilihan Supplier Terbaik Telur Bermerk Menggunakan Metode SAW Studi Kasus: PT GIANT PONDOK KOPI, vol. 3, no. 7, p. 53, 2018.

[5] R. \&. Steinbart, Pengertian Sistem, Tangerang: Gista Melandy, 2015.

[6] Turban. El. Al, Komponen Sistem Penunjang Keputusan, Bengkulu: Radias Sundoro, 2013. 